\title{
The Impact of Conventional and Sensor Spraying on Drift and Deposit in Cherry Orchard
}

\author{
Davor PETROVIĆ, Đuro BANAJ, Anamarija BANAJ, Željko BARAČ, Ivan VIDAKOVIĆ, Vjekoslav TADIĆ
}

\begin{abstract}
The research results of the spraying technical factors' impact on ground and air drift, and the deposit on the treetop in cherry orchards, are presented in the paper. Two different spraying systems (classical and sensory system) are investigated, Agromehanika AGP 200 ENU sprayer being used. The research is conducted according to ISO standard 22866 (Plant Protection Equipment - Drift Measurement Methods in Field Conditions). The impact of spraying norm as factor $A$ ( $A_{1}-250 \mathrm{l} / \mathrm{ha} ; A_{2}-200 \mathrm{l} / \mathrm{ha}$ ); the nozzle type as factor $B\left(B_{1}\right.$ - Lechler TR $8002 \mathrm{C} ; B_{2}$ - Lechler ITR $\left.8002 \mathrm{C}\right)$ and the fan air velocity as factor $C\left(C_{1}-18 \mathrm{~m} / \mathrm{s} ; C_{2}-12 \mathrm{~m} / \mathrm{s}\right)$ are examined by the variance analysis. To spray and evaluate the drift, Tartazine organic dye solution with $4 \%$ concentration is used. The filter papers, used as collectors, according to the specified ISO standard, are placed directly in the spraying zone. The sampled filter papers are washed out with $10 \mathrm{ml}$ of deionised water under laboratory conditions. After washing, the colour intensity, i.e., the solution wave-length, is read by a spectrophotometer (Varian Cary $50 \mathrm{UV}$-Visible). Different drift intensity (ground and air drift) and treetop deposits are realized by the usage of various treatments of technical spraying factors and various spraying systems. Unlike the ground and air drifts, the deposit within the treetop does not show statistically significant change by using a sensory spraying system, i.e. by using a selective application.
\end{abstract}

Keywords: air assisted sprayer; air velocity; drift; sensors; nozzles; selective application; spraying norm

\section{INTRODUCTION}

The problem of contemporary intensive agriculture is the excessive use of plant protection products both from an environmental and economic point of view. Since agriculture has become one of the major environmental polluters, concrete steps should be taken, related to the introduction of new technologies for the chemical agents' usage. That is why EU countries introduced European directive 2009/128/EZ in their legislative (In Croatia: Law on Sustainable Use of Pesticides - NN 14/14) [1]. Many authors are engaged in studying the importance of pesticide application technique. They research air velocity [2], spraying norm [3], nozzle position and orientation [4], nozzle type [5], spraying speed [6] and vertical liquid distribution [7]. The proper deposit of plant protection products is affected by various factors, such as structure and shape of the treetop, the physicochemical properties of the pesticides, agro-climate conditions and the applied spraying technique [8]-[10]. Tadić, V. [11] examines the influence of different $I S O$ type nozzles on optimum surface coverage and drift intensity within permanent crops, and states that nozzles with smaller ISO number achieve better coverage of the treated surface, but increased liquid drift, due to smaller droplets. The air mass effectiveness during spraying in permanent crops depends on the velocity and geometry of the airflow generated by the sprayer's fan [12]. Authors [13]-[15] do the research on the distribution and impact of air velocity on the leaf surface and the liquid drift with various adjustment factors. The spraying technique is significantly improved and the risk of spraying outside the targeted plant protection area reduced by installing electronic parts (electromagnetic valves, sensors, inductive encoders, etc.) on conventional sprayers [16].

The sensor system function equipped sprayers base their functions on the determination of three basic parameters: tree detection, density of leaf mass and treetop structure, i.e. breeding shape [17]. One of the problems faced by the researchers is to determine the treetop presence and shape, because based on this information the computer software determines when and how much pesticides will be used. For the high performance of selective applications, detailed information on treetop form is of crucial importance [18]. The mentioned system is designed as an improvement of conventional sprayers in terms of pesticide savings and environmental pollution reduction [19], [20]. Real-time treetop recognition by using ultrasonic sensors is researched by many scientists around the world [21]-[28]. The shape of the treetop directly affects the deposition of pesticides, and thus the effectiveness of spraying, and a greater number of authors state that the use of sensors with the possibility of detection of the treetop and its shape significantly reduces the liquid drift intensity [29]-[33]. The precision of the ultrasonic sensors is influenced by various factors: distance from the treetop, air temperature, air humidity and the speed of motion [34]. Despite the mentioned deficiencies, ultrasonic sensors are one of the most recognizable forms of tree detection in permanent crops due to their ease of use and low cost. Different visualization methods are used for the evaluation of drifts: fluorescent and visible colours, watersensitive pieces of paper, and LIDAR sensors. The most widely used is the use of fluorescent and visible colours, which are not hazardous to human use, while some of them are used in the food industry.

\section{THE RESEARCH OBJECTIVES}

The aim of the research is to determine the impact of differently adjusted spraying technical factors on ground and air drift, and the liquid deposit inside the treetop, using conventional and selective application in cherry orchard. For this purpose, Agromehanika AGP 200 ENU air assisted sprayer with a classic (axial fan sprayer with constant spraying) and sensory spraying system is used. Based on the results, it will be found out which combination of technical factors achieves the least liquid drift outside the targeted plant protection area, and that the deposit inside the treetop thereby has no significant change statistically.

\section{METHODS AND MATERIALS}

The research was carried out in a permanent cherry orchard owned by Karolina nursery-garden (Osijek, Osijek and Baranja County, Croatia) in May 2017. 
Geographical plant position $45^{\circ} 31^{\prime} 17.5^{\prime \prime} \mathrm{N}$ and $18^{\circ} 46^{\prime}$ 39.6" E.

Two different spraying systems are researched using Agromehanika AGP 200 ENU sprayer. The sprayer is equipped with altitudinal air routers of $136 \mathrm{~cm}$ height and $11 \mathrm{~cm}$ width (Fig. 1). The fan diameter is $585 \mathrm{~mm}$ proportionally adjustable in five positions. The airflow output velocity ranges from 10 to $35 \mathrm{~m} / \mathrm{s}$. The sprayer is manufactured in accordance with the European standard EN 13790 with three liquid containers, the main tank being 200 litres. A piston - membrane pump with a capacity of $61.64 \mathrm{l} / \mathrm{min}$ (pump type $B M$ 65/30 with two membranes) to a maximum working pressure of 30 bar, produced by Agromehanika, was installed on the sprayer. The airflow velocity is adjusted by changing the blade position on the fan.

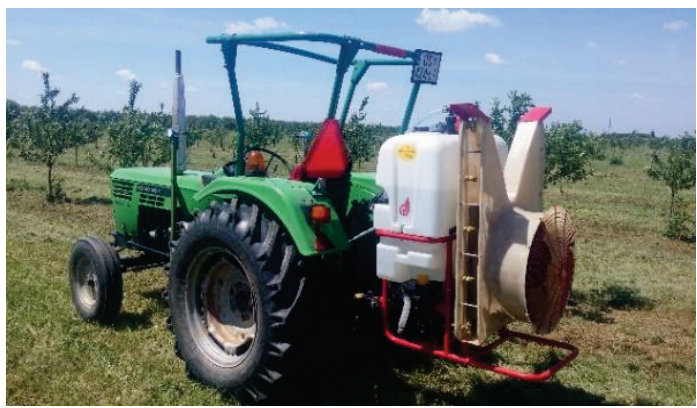

Figure 1 Air assisted sprayer Agromehanika AGP 200 ENU

The Sick ultrasonic sensor system model UM30-215111 (Fig. 2) has the ability to detect objects at a distance of 0.6 to $6 \mathrm{~m}$, and the minimum surface area of the object that can be detected is $0.02 \mathrm{~m}^{2}\left(2 \mathrm{~cm}^{2}\right)$. Target object detection speed is $240 \mathrm{~ms}$ and is labelled by the $I P$ 67 certificate. The sensors are controlled by Bravo $140 \mathrm{~s}$ computer, produced by Arag manufacturer, with the option to manually and automatically control the delay of spraying time. An inductive signal transducer, connected to the mentioned computer, is used to measure the speed motion of the aggregate.

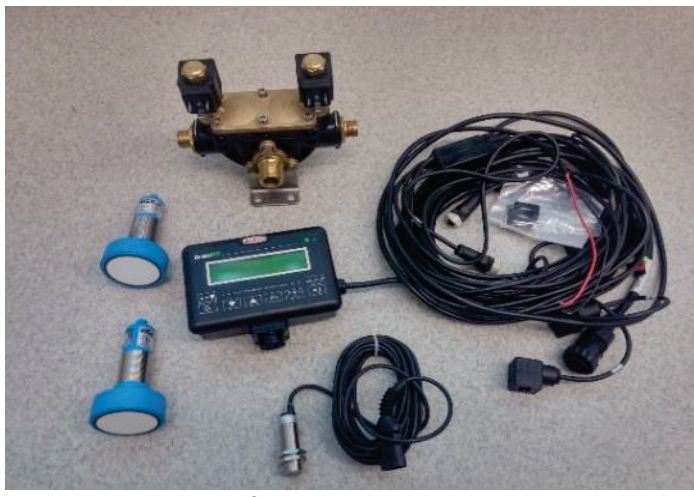

Figure 2 Sick company sensors system

The standard Lechler TR 8002 C nozzle, which is of a hollow conical design, generates a spray at a working angle of $80^{\circ}$, and is mostly used for the protection of orchards and vineyards. The nozzle flow rate is $0.8 \mathrm{l} / \mathrm{min}$ at a $3 \mathrm{bar}$ working pressure. The nozzle is made of polymers with a ceramic insert. Due to small drops [35], generated during application, good coverage of the treated surface is obtained, with high sensitivity to liquid drift.
The air injector cone nozzle of the Lechler type ITR $8002 C$ (Fig. 3) is specially designed to reduce liquid drift. The nozzle body is made of polymers with a removable wear resistant ceramic insert that can be exchanged. A 0.8 $1 / \mathrm{min}$ flow is achieved at a pressure of 3 bar and the spraying angle is $80^{\circ}$. The droplet size spectrum is large to extremely large [35], which greatly reduces the occurrence of liquid drift. This type of nozzles generates bigger droplets than $T R$ nozzles because of the air and fluid mixing in the body of nozzle, and by that forming air droplets.

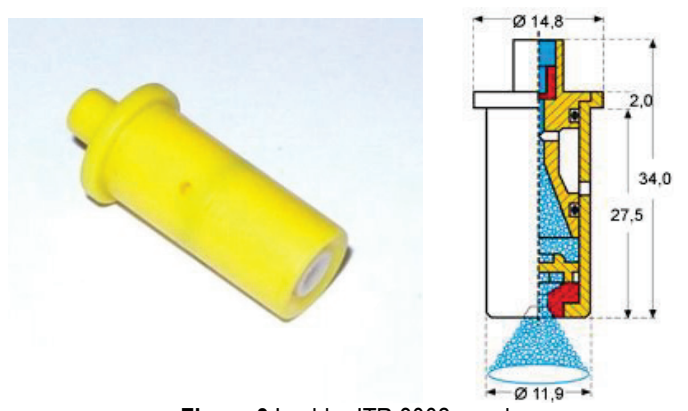

Figure 3 Lechler ITR 8002 nozzle

During the research, Tartrazine organic dye with a $4 \%$ (Acros Organics) concentration was used to colour the liquid with which the application was performed. It is easily water-soluble and is not harmful to human health. Filter pieces of paper $\left(35 \mathrm{~cm}^{2}\right)$, produced by Technofil, are used as collectors. Filter papers (30 pieces in 4 repetition) for ground drift are positioned at horizontal collector on the ground between two trees in treated row. Length of collector is $20 \mathrm{~m}$, and filter papers are placed at every 50 $\mathrm{cm}$ on first $10 \mathrm{~m}$, and at every $1 \mathrm{~m}$ on second $10 \mathrm{~m}$. Filter papers for air drift are placed $5 \mathrm{~m}$ vertically on collector at two distances from treated row: 5 and $10 \mathrm{~m}$. On every collector 10 filter papers are placed at distance of $50 \mathrm{~cm}$. Fig. 4 shows the filter papers set in the treetop.

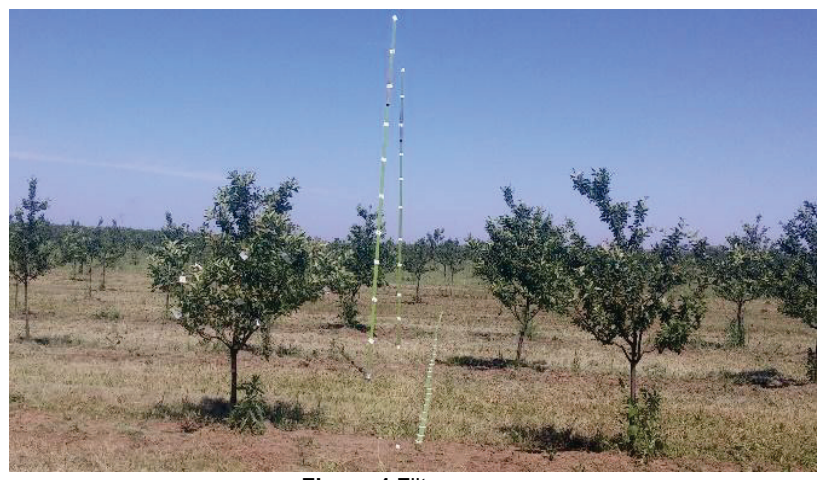

Figure 4 Filter papers

The research is set up in accordance with ISO 22866 (Plant Protection Equipment - Drift Measurement Methods in Field Conditions). Breeding form of cherry orchard is a repaired pyramid. After each treatment, the filter pieces of paper are collected during 15 minutes' time and stored in the hermetically sealed bags that are stored in a place without the access to sunlight. In the laboratory, the sampled filter pieces of paper are washed out with 10 $\mathrm{ml}$ of deionised water, after which the concetration of dyew in solution is determined by a wave-length of 425 $\mathrm{nm}$, read on the spectrophotometer (Varian Cary $50 \mathrm{UV}$ - 
Visible). The obtained values are used for the calculation of liquid drift $\left(\mu \mathrm{g} / \mathrm{cm}^{2}\right)$. The calculation of deposits per unit of surface is done by means of the Eq. (1) [26] where; $M_{\mathrm{d}}$ - deposit of the liquid on the collector $\left(\mu \mathrm{g} / \mathrm{cm}^{2}\right), T_{\mathrm{cl}}$ concentration of the application colour $(\mu \mathrm{g} / \mathrm{ml}), w-$ the amount of deionised water for the collector washout $(\mathrm{ml})$ and $L_{\mathrm{a}}$ - collector surface - filter pieces of paper $\left(\mathrm{cm}^{2}\right)$.

$$
M_{\mathrm{d}}=\frac{T_{\mathrm{cl}} \cdot w}{L_{\mathrm{a}}}
$$

The spraying air flow rate is adjusted to the growing shape and density of the leaf surface. So, for plants with a lush treetop, the air velocity should be set to higher values and vice versa. The theoretical air flow required for the application in a particular plantation can be determined according to the expression [3]:

$Q_{z}=\frac{1000 \cdot v \cdot b_{\mathrm{m}} \cdot h_{\mathrm{n}}}{f}$

where is: $Q_{z}-$ airflow, $\mathrm{m}^{3} / \mathrm{h} ; v-$ spraying speed, $\mathrm{km} / \mathrm{h} ; b_{\mathrm{m}}$ - spray width, $\mathrm{m} ; h_{\mathrm{n}}$ - height of plant, $\mathrm{m} ; f$-foliation factor (for lush plants $1.5-2.5$ and for less $2.5-3.5$ ).

As a factor $A$, the spraying norm is tested. The optimum spraying norm $A_{l}(250 \mathrm{l} / \mathrm{ha}$ - calculated according to the current state of planting and volume of leaf mass) is used, and the $A_{2}$ spraying norm, which is reduced by $30 \%(200$
$1 /$ ha). As the second technical factor, the impact of standard nozzle $B_{1}$ (Lechler TR $8002 \mathrm{C}$ ) and the nozzles with reduced liquid drift - factor $B_{2}$ (Lechler ITR $8002 \mathrm{C}$ ) is observed. Factor $C$ denotes the impact of the airflow on the liquid drift. $C_{1}$ denotes the fan air velocity, calculated according to the leaf mass volume $\left(2^{\text {nd }}\right.$ blade position according to technical specifications - $18 \mathrm{~m} / \mathrm{s}$ ) and air velocity reduced by $30 \%$ ( $1^{\text {st }}$ blade position according to technical specifications $12 \mathrm{~m} / \mathrm{s}$ ) - factor $C_{2}$. The weather conditions during the research are monitored by Hobo's mobile meteorological station. The following factors are kept track of: wind speed, wind direction, temperature, relative humidity, i.e. all parameters that have a direct impact on the technical factors of plant protection. For statistical analysis of the research results, the $S A S$ enterprise guide version 7.15 and Microsoft Office Excell 2016 are used.

\section{RESULTS}

Tab. 1 shows the average weather conditions values during the research. The average air temperature was $21.95{ }^{\circ} \mathrm{C}$, relative humidity was $61.66 \%$ and wind speed was from 0.55 to $0.76 \mathrm{~m} / \mathrm{s}$ during the probe with a sensorfree spraying. The weather conditions during the probe with sensor spraying were of very similar values: the average air temperature $21.93{ }^{\circ} \mathrm{C}$, relative humidity $61.60 \%$, wind speed from 0.55 to $0.66 \mathrm{~m} / \mathrm{s}$.

Table 1 Weather conditions

\begin{tabular}{|c|c|c|c|c|c|c|c|c|c|c|c|c|}
\hline \multicolumn{13}{|c|}{ Conventional spraying } \\
\hline \multicolumn{2}{|c|}{ Treatments } & $A_{1} B_{1} C_{1}$ & $A_{1} B_{1} C_{2}$ & $A_{1} B_{2} C_{1}$ & $A_{1} B_{2} C_{2}$ & $A_{2} B_{1} C_{1}$ & $A_{2} B_{1} C_{2}$ & $A_{2} B_{2} C_{1}$ & $A_{2} B_{2} C_{2}$ & $\underline{X}$ & $\sigma$ & $\begin{array}{l}\text { C.V. } \\
(\%)\end{array}$ \\
\hline \multicolumn{2}{|c|}{$T_{\mathrm{z}}\left({ }^{\circ} \mathrm{C}\right)$} & 22.3 & 21.3 & 19.2 & 23.4 & 23.1 & 19.8 & 24.3 & 22.2 & 21.95 & 1.76 & 8.03 \\
\hline \multicolumn{2}{|c|}{$\omega_{\mathrm{z}}(\%)$} & 60.2 & 63.8 & 70.6 & 58.4 & 58.5 & 68.3 & 54.2 & 59.3 & 61.66 & 5.51 & 8.94 \\
\hline \multirow{3}{*}{$\begin{array}{c}v_{\mathrm{v}} \\
(\mathrm{m} / \mathrm{s})\end{array}$} & Min. & 0.5 & 0.6 & 0.7 & 0.5 & 0.2 & 0.4 & 0.4 & 1.1 & 0.55 & 0.27 & 48.59 \\
\hline & Max. & 1.1 & 0.8 & 0.8 & 0.6 & 0.4 & 0.6 & 0.7 & 1.4 & 0.80 & 0.32 & 39.53 \\
\hline & $\underline{X}$ & 0.8 & 0.7 & 0.75 & 0.55 & 0.3 & 0.5 & 0.55 & 1.25 & 0.68 & 0.28 & 41.72 \\
\hline \multicolumn{13}{|c|}{ Sensor spraying } \\
\hline \multirow{2}{*}{\multicolumn{2}{|c|}{$\begin{array}{l}T_{\mathrm{z}}\left({ }^{\circ} \mathrm{C}\right) \\
\omega_{\mathrm{z}}(\%)\end{array}$}} & 22.4 & 20.9 & 19.4 & 23.4 & 23.1 & 19.8 & 24.2 & 22.2 & 21.93 & 1.73 & 7.90 \\
\hline & & 60.1 & 63.9 & 70.1 & 58.4 & 58.5 & 68.3 & 54.2 & 59.3 & 61.60 & 5.41 & 8.78 \\
\hline \multirow{3}{*}{$\begin{array}{c}v_{\mathrm{v}} \\
(\mathrm{m} / \mathrm{s})\end{array}$} & Min. & 0.6 & 0.5 & 0.9 & 0.6 & 0.3 & 0.6 & 0.7 & 0.9 & 0.64 & 0.20 & 31.30 \\
\hline & Max. & 1.1 & 0.6 & 0.8 & 0.8 & 0.4 & 0.7 & 1.1 & 1.4 & 0.86 & 0.32 & 37.15 \\
\hline & $\underline{X}$ & 0.85 & 0.55 & 0.85 & 0.7 & 0.35 & 0.65 & 0.9 & 1.15 & 0.75 & 0.24 & 32.46 \\
\hline
\end{tabular}

$T_{\mathrm{z}}$ - air temperature in the orchard; $\omega_{\mathrm{z}}$ - relative air humidity in the orchard; $v_{\mathrm{v}}$ - wind speed

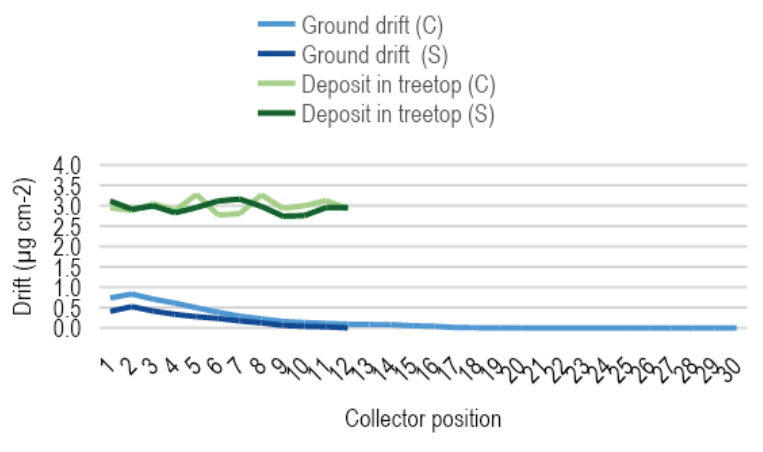

Figure 5 Ground drift and deposit

Fig. 5 shows the average value of ground drift and deposits per unit area $\mu \mathrm{g} / \mathrm{cm}$ (for all conventional and sensory spraying treatments). It can be seen from Fig. 5 that by increasing the distance from the treated row, the value of the ground drift decreases, while the deposit inside the treetop remains unchanged. The achieved air drift values on the collectors placed in the direct spraying zone at a distance of 5 and 10 meters, conventional (C) and sensory (S) spraying modes being used, are shown in Fig. 6 (collectors placed every $0.5 \mathrm{~m}$ to total height of $5 \mathrm{~m}$ ). The mentioned figure shows the reduction of air drift by increasing the distance and height of the collector.

Fig. 7 shows the distribution of the drifted liquid in the form of the ground drift. The liquid distribution in the form of the air drift, collected on a support $5 \mathrm{~m}$ away from the treated row, is shown in Fig. 8, while Fig. 9 shows the distribution of the collected drift on a $10 \mathrm{~m}$ distant support.

The distribution of the deposits within the treetop, achieved by various combinations of the main technical drift factors, is shown in Fig. 10. 


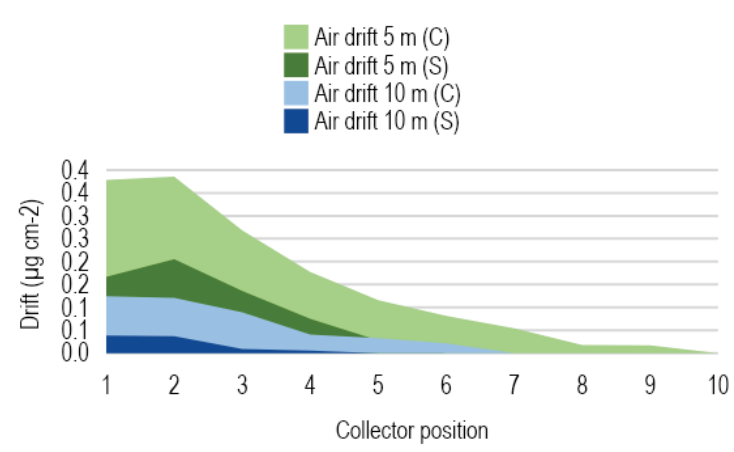

Figure 6 Air drift on 5 and $10 \mathrm{~m}$

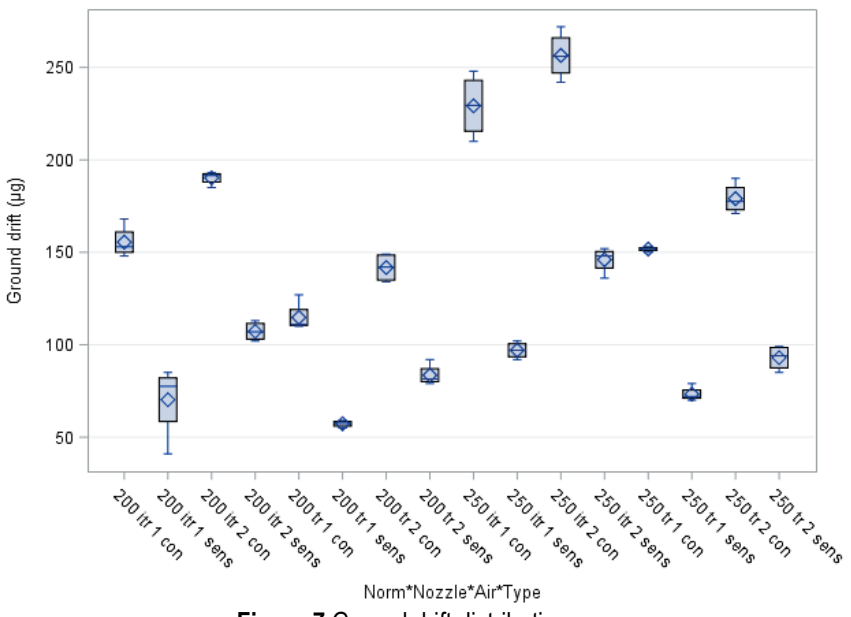

Figure 7 Ground drift distribution

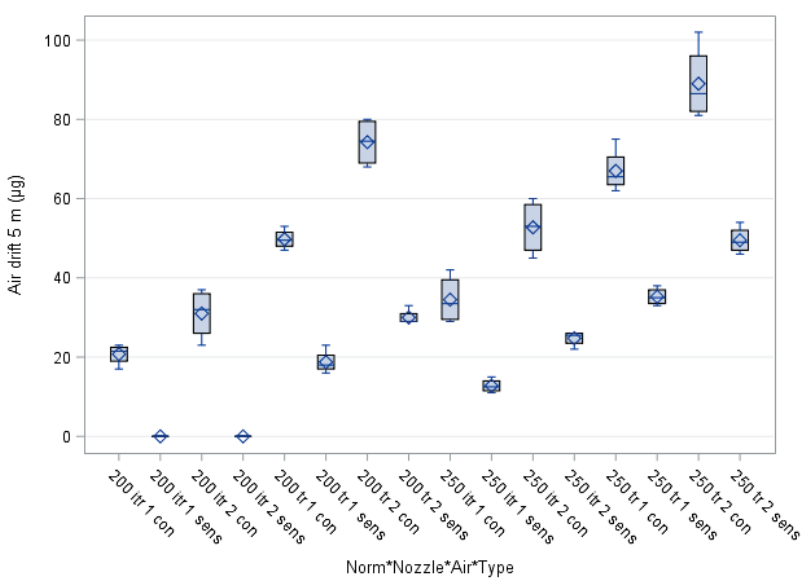

Figure 8 Air drift distribution at $5 \mathrm{~m}$ distance from the treated row

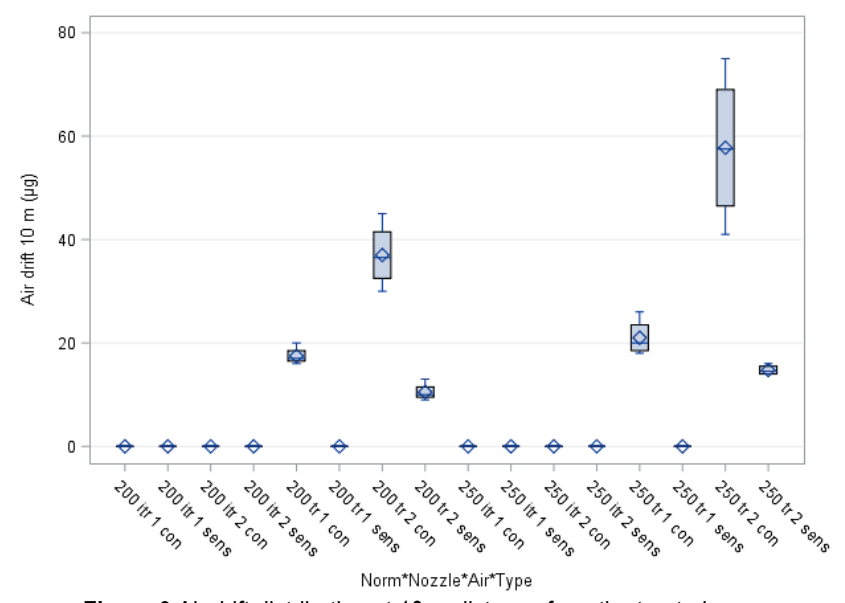

Figure 9 Air drift distribution at $10 \mathrm{~m}$ distance from the treated row

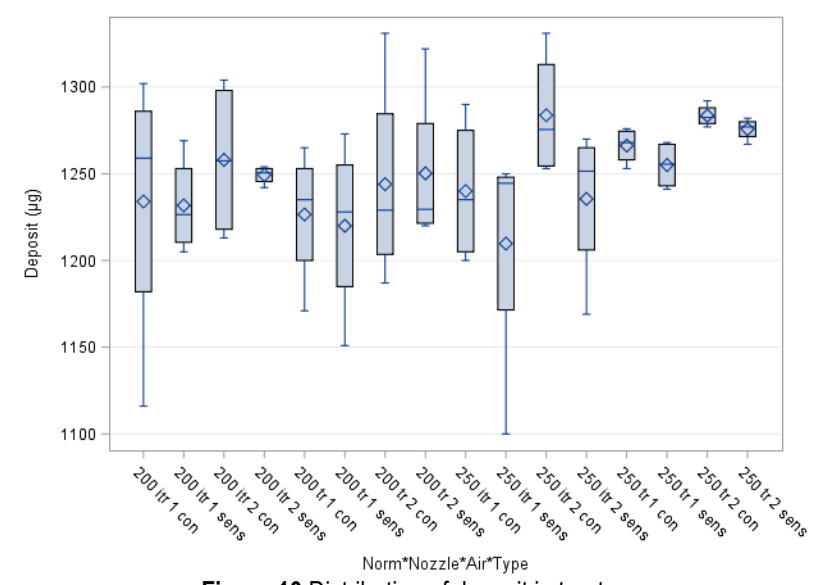

Figure 10 Distribution of deposit in treetop

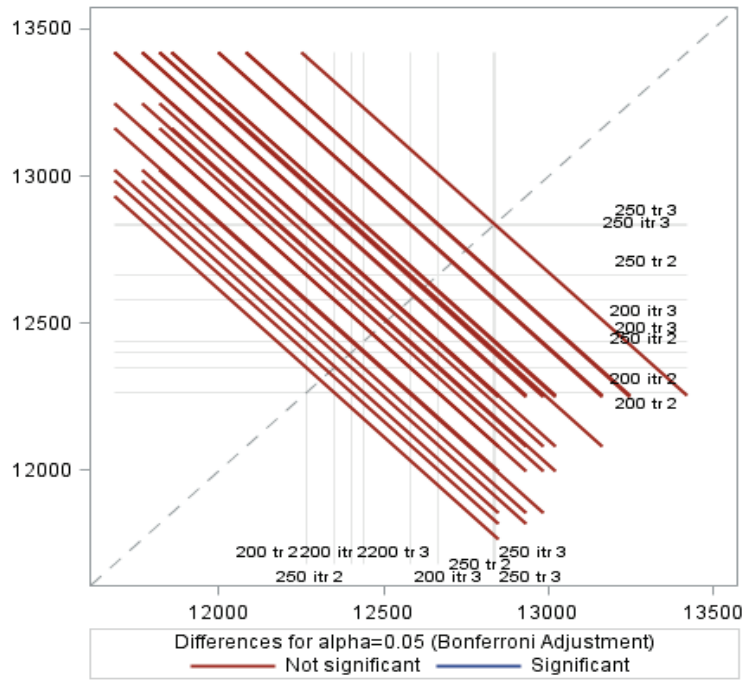

Figure 11 The impact of the interaction of the main technical spraying factors on liquid deposit in treetop - conventional spraying

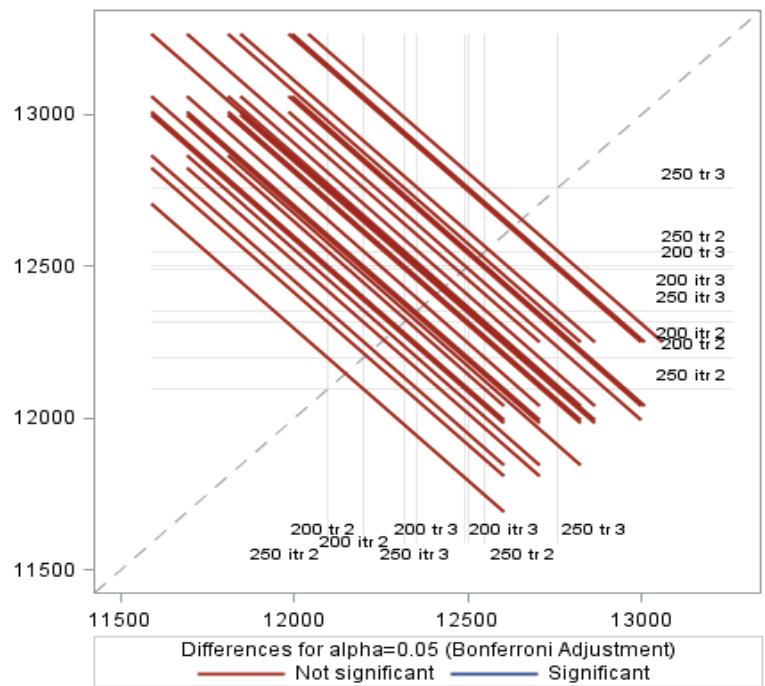

Figure 12 The impact of the interaction of the main technical spraying factors on liquid deposit in treetop - sensory spraying

The impact of the interaction of the spraying norm, the nozzle type and the airflow velocity on the deposit within the treetop is shown in Figs. 11 and 12 (charts from SAS). It is evident that, by different spraying systems being used, the interaction of the factors does not have a statistically significant impact on the liquid deposit inside the treetop. Figs. 7-10 show the total distribution of the dependent 
variables according to treatments. According to ISO standard 22866, the sampled surface for ground drift is $1.050 \mathrm{~cm}^{2}$; for air drift is $350 \mathrm{~cm}^{2}$, and for the deposit 420 $\mathrm{cm}^{2}[36]$.

Tab. 2 shows that the main technical spraying factors (spraying norm, nozzle type and airflow velocity) have a statistically significant impact on the ground and air drift at 5 and 10 meters from the middle of the treated row, both in the conventional spraying system, as well as in the sensory spraying system. Applying different spraying systems, there is no statistically significant change in the liquid deposit in the treetop.

Post hoc data analysis and the $L S D_{0.05}$ test's application (Tab. 3) indicate that, conventional spraying mode being used, the ground drift value decreases by changing the spraying norm. The nozzle type has a statistically significant impact on the reduction of the ground drift, while the change in air velocity did not have a significant impact on the ground drift reduction. By decreasing the main technical spraying factors' value, there is no statistically significant change within the treetop deposit. It is noted from the above given table that the reduction of the spraying norm, air velocity and the ITR nozzle usage have a statistically significant impact on the reduction of air drift at 5 meters. Ground drift values collected at a distance of 10 meters statistically do not change significantly by changing the spraying norm and air velocity. However, the nozzle type significantly affects the drift reduction. Furthermore, the table shows that the lowest values of ground and air drift have been achieved by using a spraying system with detectors for the treetop presence. Applying the said system, there is no statistically significant change in the liquid deposit in the treetop.

Table 2 Analysis of variance for the main properties of the research

\begin{tabular}{|c|c|c|c|c|c|c|c|c|}
\hline \multicolumn{9}{|c|}{ Conventional spraying } \\
\hline \multirow{3}{*}{$\begin{array}{c}\text { ANOVA } \\
A\end{array}$} & \multicolumn{2}{|c|}{ Ground drift } & \multicolumn{2}{|c|}{ Deposit } & \multicolumn{2}{|c|}{ Air drift $-5 \mathrm{~m}$} & \multicolumn{2}{|c|}{ Air drift $-10 \mathrm{~m}$} \\
\hline & $F$-test & $p$ & $F$-test & $p$ & $F$-test & $p$ & $F$-test & $p$ \\
\hline & $249.50 *$ & $<.0001$ & 2.74 n.s. & 0.11 & $61.16^{*}$ & $<.0001$ & $8.78^{*}$ & 0.007 \\
\hline$B$ & $324.27 *$ & $<.0001$ & 0.00 n.s. & 0.96 & $266.86^{*}$ & $<.0001$ & $265.09 *$ & $<.0001$ \\
\hline$C$ & $73.45^{*}$ & $<.0001$ & 2.33 n.s. & 0.14 & $75.50^{*}$ & $<.0001$ & $47.24^{*}$ & $<.0001$ \\
\hline$A B$ & $23.50 *$ & $<.0001$ & 0.53 n.s. & 0.47 & 0.16 n.s. & 0.69 & $8.78^{*}$ & 0.007 \\
\hline$A C$ & 0.29 n.s. & 0.60 & 0.10 n.s. & 0.76 & 0.41 n.s. & 0.53 & 4.44 n.s. & 0.05 \\
\hline$B C$ & 0.33 n.s. & 0.57 & 0.23 n.s. & 0.63 & 4.35 n.s. & 0.05 & $47.24 *$ & $<.0001$ \\
\hline$A B C$ & 0.33 n.s. & 0.57 & 0.10 n.s. & 0.75 & 1.48 n.s. & 0.24 & 4.44 n.s. & 0.05 \\
\hline \multicolumn{9}{|c|}{ Sensor spraying } \\
\hline \multirow{2}{*}{ ANOVA } & \multicolumn{2}{|c|}{ Ground drift } & \multicolumn{2}{|c|}{ Deposit } & \multicolumn{2}{|c|}{ Air drift $-5 \mathrm{~m}$} & \multicolumn{2}{|c|}{ Air drift $-10 \mathrm{~m}$} \\
\hline & $F$-test & $p$ & $F$-test & $p$ & $F$-test & $p$ & $F$-test & $p$ \\
\hline$A$ & $56.59 *$ & $<.0001$ & 0.18 n.s. & 0.67 & $600.25 *$ & $<.0001$ & $18.45^{*}$ & 0.0002 \\
\hline$B$ & $88.03 *$ & $<.0001$ & 1.66 n.s. & 0.21 & $10.24 *$ & $<.0001$ & $651.13 *$ & $<.0001$ \\
\hline$C$ & $119.07 *$ & $<.0001$ & 2.64 n.s. & 0.12 & $156.25^{*}$ & $<.0001$ & 651.13* & $<.0001$ \\
\hline$A B$ & $10.93 *$ & 0.003 & 2.75 n.s. & 0.11 & 0.25 n.s. & 0.62 & $18.45^{*}$ & 0.0002 \\
\hline$A C$ & 0.21 n.s. & 0.65 & 0.00 n.s. & 0.98 & $25.00 *$ & $<.0001$ & $18.45^{*}$ & 0.0002 \\
\hline$B C$ & $10.93 *$ & 0.003 & 0.02 n.s. & 0.89 & $20.25^{*}$ & 0.0001 & $651.13 *$ & $<.0001$ \\
\hline$A B C$ & 2.34 n.s. & 0.14 & 0.09 n.s. & 0.76 & $9.00 *$ & 0.006 & $18.45^{*}$ & 0.0002 \\
\hline
\end{tabular}

$\alpha=0,05 ; A-$ spraying norm $\left(A_{1}-2501 /\right.$ ha; $A_{2}-2001 /$ ha $), B$ - nozzle type $\left(B_{1}-\right.$ Lechler TR $8002 C ; B_{2}-$ Lechler ITR $\left.8002 C\right), C-$ air flow rate $\left(C_{1}-18\right.$ $\left.\mathrm{m} / \mathrm{s} ; C_{2}-12 \mathrm{~m} / \mathrm{s}\right)$

Table 3 Means and LSD test for the main properties of the research

\begin{tabular}{|c|c|c|c|c|c|c|c|c|c|}
\hline \multicolumn{10}{|c|}{ Conventional spraying } \\
\hline & & \multicolumn{2}{|c|}{ Ground drift } & \multicolumn{2}{|c|}{ Deposit } & \multicolumn{2}{|c|}{ Air drift $-5 \mathrm{~m}$} & \multicolumn{2}{|c|}{ Air drift - $10 \mathrm{~m}$} \\
\hline & & $\underline{X}$ & $L S D_{0.05}$ & $\underline{X}$ & $L S D_{0.05}$ & $\underline{X}$ & $L S D_{0.05}$ & $\underline{X}$ & $L S D_{0.05}$ \\
\hline \multirow{2}{*}{$A$} & $A_{1}$ & 204.13 & \multirow{2}{*}{$26.70^{*}$} & 1268.38 & \multirow{2}{*}{32.36 n.s. } & 60.81 & \multirow{2}{*}{$15.53 *$} & 19.68 & \multirow{2}{*}{15.28 n.s. } \\
\hline & $A_{2}$ & 150.56 & & 1240.88 & & 43.93 & & 13.62 & \\
\hline \multirow{2}{*}{$B$} & $B_{1}$ & 207.78 & \multirow{2}{*}{$24.36^{*}$} & 1254.19 & \multirow{2}{*}{33.94 n.s. } & 70.00 & \multirow{2}{*}{$10.39 *$} & 33.31 & \multirow{2}{*}{$9.18^{*}$} \\
\hline & $B_{2}$ & 146.81 & & 1255.06 & & 34.75 & & 0.00 & \\
\hline \multirow{2}{*}{$C$} & $C_{1}$ & 191.88 & \multirow{2}{*}{31.53 n.s. } & 1257.31 & \multirow{2}{*}{32.60 n.s. } & 61.75 & \multirow{2}{*}{$15.23^{*}$} & 23.68 & \multirow{2}{*}{14.53 n.s. } \\
\hline & $C_{2}$ & 162.81 & & 1241.94 & & 43.00 & & 9.62 & \\
\hline \multicolumn{10}{|c|}{ Sensor spraying } \\
\hline \multirow{2}{*}{$A$} & $A_{1}$ & 102.31 & \multirow{2}{*}{$18.02 *$} & 1244.00 & \multirow{2}{*}{30.19 n.s. } & 30.56 & \multirow{2}{*}{$9.92 *$} & 3.68 & \multirow{2}{*}{4.15 n.s. } \\
\hline & $A_{2}$ & 79.56 & & 1237.81 & & 12.18 & & 2.62 & \\
\hline \multirow{2}{*}{$B$} & $B_{1}$ & 105.12 & \multirow{2}{*}{$16.88^{*}$} & 1250.25 & \multirow{2}{*}{29.46 n.s. } & 33.37 & \multirow{2}{*}{$8.08 *$} & 6.31 & \multirow{2}{*}{$3.45^{*}$} \\
\hline & $B_{2}$ & 76.75 & & 1231.60 & & 9.37 & & 0.00 & \\
\hline \multirow{2}{*}{$C$} & $C_{1}$ & 107.43 & \multirow{2}{*}{$15.67 *$} & 1252.69 & \multirow{2}{*}{28.97 n.s. } & 26.06 & \multirow{2}{*}{$11.54^{*}$} & 6.31 & \multirow{2}{*}{$3.45^{*}$} \\
\hline & $C_{2}$ & 74.43 & & 1229.13 & & 16.68 & & 0.00 & \\
\hline
\end{tabular}
$A$ - spraying norm $\left(A_{1}-250 \mathrm{l} / \mathrm{ha} ; A_{2}-200 \mathrm{l} / \mathrm{ha}\right), B$ - nozzle type $\left(B_{1}-\right.$ Lechler TR $8002 \mathrm{C} ; B_{2}-$ Lechler ITR $\left.8002 \mathrm{C}\right), C-$ air flow rate $\left(C_{1}-18 \mathrm{~m} / \mathrm{s} ; C_{2}-\right.$ $12 \mathrm{~m} / \mathrm{s}$ )

Table 4 Conventional and sensor spraying differences

\begin{tabular}{|c|c|c|c|c|c|c|c|c|}
\hline \multirow{3}{*}{$\begin{array}{c}\text { Spraying systems } \\
\text { Conventional }\end{array}$} & \multicolumn{4}{|c|}{ Ground drift } & \multicolumn{4}{|c|}{ Deposit } \\
\hline & $\underline{X}$ & $F$-test & $p$ & $L S D_{0.05}$ & $\underline{X}$ & $F$-test & $p$ & $L S D_{0.05}$ \\
\hline & 17,73 & \multirow{2}{*}{$85.30^{*}$} & \multirow{2}{*}{$<.0001$} & \multirow{2}{*}{1,87} & 125.47 & \multirow{2}{*}{1,57 n.s. } & \multirow{2}{*}{0.215} & \multirow{2}{*}{2,19} \\
\hline Sensors & 9,09 & & & & 124.10 & & & \\
\hline & \multicolumn{4}{|c|}{ Air drift - $5 \mathrm{~m}$} & \multicolumn{4}{|c|}{ Air drift $-10 \mathrm{~m}$} \\
\hline Conventional & 5,24 & \multirow{2}{*}{$38,86^{*}$} & \multirow{2}{*}{$<.0001$} & \multirow{2}{*}{0,99} & 1,67 & \multirow{2}{*}{$12,27^{*}$} & \multirow{2}{*}{0.0009} & \multirow{2}{*}{0,77} \\
\hline Sensors & 2,14 & & & & 0,32 & & & \\
\hline
\end{tabular}


The statistically significant reduction of the ground drift is achieved by using the sensory spraying method. By comparing these two spraying systems (sensory and conventional) the value of deposits within the treetop statistically does not significantly change. The decrease of the ground drift, applied at $5 \mathrm{~m}$ from the treated row, is statistically significant thanks to the sensor system usage. The same is noted by the air drift at a $10 \mathrm{~m}$ distance - Tab. 4.

\section{CONCLUSION}

World trends related to optimizing the main technical factors of pesticide spraying for the purpose of human health protection and environmental pollution prevention are followed by this research. Therefore, the possibility of reducing the standard of spraying, air velocity and the application of special drift reduction nozzles are examined. In addition, using a sensor-enhanced system for the occurrence of ground and air drift, and the deposition of liquid in the treetop, the influence of selective application was researched. Having the obtained results in mind, it can be concluded that the main technical spraying parameters have a statistically significant impact on the reduction of the drift phenomenon, both ground and air drift, at 5 and 10 meters distance from the treated row. Using the sensory spraying method in the cherry orchard, the accomplished reduction in ground drift is $48.74 \%$. The same spraying system reduces the air drift at 5 meters from the treated area by $59.16 \%$, while for the ground drift at $10 \mathrm{~m}$, it has decreased by $80.83 \%$. The deposit within the treetop does not show statistically significant change (it remains unchanged) in all combinations of spraying factors. The use of a sensor system, in order to reduce drifts in permanent crops, has fully justified the expectations and significantly reduced losses, which is ultimately leading to a long-term sustainable agricultural production and its cost lowering.

\section{REFERENCES}

[1] https://www.zakon.hr/z/703/Zakon-o-odr\%C5\%BEivojuporabi-pesticida

[2] Wei, Q., Sanqin, Z., Weimin, D., Chengda, S., Jiang, L., Yinian, L., \& Jiabing, G. (2016). Effects of fan speed on spray deposition and drift for targeting air-assisted sprayer in pear orchard. Int J Agric \& Biol Eng., 9(4), 53.

https://www.ijabe.org/index.php/ijabe/article/viewFile/1938 $/ \mathrm{pdf}$

[3] Tadić, V., Marković, M., Plaščak, I., Stošić, M., Lukinac Čačić, J., \& Vujčić, B. (2014). Impact of technical spraying factors on leaf area coverage in an apple orchard. Tehnički vjesnik, 21(5), 1117-1124.

https://hrcak.srce.hr/index.php?show=clanak\&id_clanak_je $\mathrm{zik}=190713$

[4] Landers, A. \& Farooq, M. (2004). Reducing Spray Drift from Orchards. New York Fruit Quarterly, 12, 23-26. http://citeseerx.ist.psu.edu/viewdoc/download?doi=10.1.1.6 $56.666 \&$ rep $=$ rep $1 \&$ type $=$ pdf

[5] Derksen, R.C., Zhu, H., Fox, R. D., Brazee, R. D., \& Krause, C. R. (2007). Coverage and drift produced by air induction and conventional hydraulic nozzles used for orchard applications. Trans. ASABE, 50, 1493-1501. https://doi.org/10.13031/2013.23941
[6] Celen, I. H., Arin, S., \& Durgut, M. R. (2008). The effect of the air blast sprayer speed on the chemical distribution in vineyard. Pak. J. Biol. Sci., 11, 1472-1476. https://doi.org/10.3923/pjbs.2008.1472.1476

[7] Vujčić, B., Tadić V., Marković, M., Lukinac-Čačić, J., Stošić, M., Plaščak, I. (2015). Impact of technical spraying factors on vertical liquid distribution with Agromehanika AGP 440 axial fan sprayer. Tehnički vjesnik, 22(2), 367-373. https://doi.org/10.17559/TV-2014033114184

[8] Larbi, P. A. \& Salyani, M. (2012). Model to predict spray deposition in citrus airblast sprayer applications: Part 2. Spray deposition. Trans. ASABE, 55, 41-48. https://doi.org/10.13031/2013.41246

[9] Dorr, G. J., Hewitt, A. J., Adkins, S. W., Hanan, J., Zhang, H., \& Noller, B. (2013). A comparison of initial spray characteristics produced by agricultural nozzles. Crop Protection, 53, 109-117. https://doi.org/10.1016/j.cropro.2013.06.017

[10] Vallet, A. \& Tinet, C. (2013). Characteristics of droplets from single and twin jet air induction nozzles: a preliminary investigation. Crop Protection, 48, 63-68. https://doi.org/10.1016/j.cropro.2013.02.010

[11] Tadić, V. (2013). Impact of technical spraying factors on leaf area coverage in permanent crops. PhD thesis, Agricultural faculty in Osijek. http://www.pfos.unios.hr/hr/knjiznica/ doktorske-disertacije/

[12] Panneton, B., Lacasse, B., \& Piche, M. (2005). Effect of airjet configuration on spray coverage invineyards. Biosyst. Eng., 90, 173-184. https://doi.org/10.1016/j.biosystemseng.2004.11.001

[13] Tadić, V., Banaj, Đ., Petrović, D., Knežević, D., Lukinac Čačić, J., \& Menđušić, I. (2014). Air flow and velocity with different types of mistblowers. Agronomski glasnik, 75(4), 181-196. https://hrcak.srce.hr/index.php?show=clanak\&id clanak_jezik $=175141$

[14] Banaj, Đ., Tadić, V., Petrović, D., Knežević, D., \& Banaj, A. (2014). Vertical distribution of air current with $A G P 200$ ENU mistblower. Proceedings of the $42^{\text {nd }}$ International Symposium on Agricultural Engineering; 167-177. http://atae.agr.hr/Zbornik_2014.pdf

[15] Banaj, A., Tadić, V., Petrović, D., Knežević, D., Banaj, Đ., \& Duvnjak, V. (2016). Vertical distribution of air current with AGP 200 ENU and Tifone Vento mistblower. Proceedings of the $4^{\text {th }}$ International Symposium on Agricultural Engineering, 167-175. https://www.cabdirect.org/cabdirect/abstract/20163246093

[16] Llorens Calveras, J., Landers, A. J., \& Larzelere, W. (2013). Precision application of pesticides in orchards - adjusting liquid flow. NY Fruit Quarterly, 21(4), 7-10. http://nyshs.org/wp-content/uploads/2016/10/Pages-7-12from-NYFQ-Winter-12-12-2013.cmc_pdf

[17] Fox, R. D., Derksen, R. C., Zhu, H., Brazee, R. D., \& Svensson, S. (2008). A history of air-blast sprayer development and future prospects. Trans. ASABE, 51(2), 405-410. https://doi.org/10.13031/2013.24375

[18] Llorens, J., Gil, E., Llop, J., \& Escola, A. (2011). Ultrasonic and LIDAR Sensors for Electronic Canopy Characterization in Vineyards: Advances to Improve Pesticide Application Methods. Sensors (Basel), 11, 2177-2194. https://doi.org/10.3390/s110202177

[19] Solanelles, F., Escola, A., Planas, S., Rosell, J. R., Camp, F., \& Gracia, F. (2006). An electronic control system for pesticide application proportional to the canopy width of tree crops. Biosystems Eng., 95(4), 473-481. https://doi.org/10.1016/j.biosystemseng.2006.08.004

[20] Jeon, H. Y. \& Zhu, H. (2012). Development of a variablerate sprayer for nursery liner applications. Trans. ASABE, 55(1), 303-312. https://doi.org/10.13031/2013.41240 
[21] Perry, R. \& Cordero, R. (1995). Sensor controlled orchard sprayers. Proceedings of the National Conference on Pesticide Application Technology, Guelph, 164-171.

[22] Balsari, P. \& Tamagnone, M. (1998). An ultrasonic airblast sprayer. Proceedings of the International Conference on Agricultural Engineering, 585-586. https://iris.unito.it/ handle/2318/19930\#.WroQcIhuaHs

[23] Moltó, E., Martín, B., \& Gutiérrez, A. (2000). PM-Power and Machinery: Design and testing of an automatic machine for spraying at a constant distance from the tree canopy. Journal of Agricultural Engineering Research, 77, 379-384. https://doi.org/10.1006/jaer.2000.0621

[24] Schumann, A. \& Zaman, Q. (2005). Software development for real-time ultrasonic mapping of tree canopy size. Computers and Electronics in Agriculture, 47, 25-40. https://doi.org/10.1016/j.compag.2004.10.002

[25] Solanelles, F., Escola, A., Planas, S., Rosell, J. R., Camp, F., \& Gracia, F. (2006). An electronic control system for pesticide application proportional to the canopy width of tree crops. Biosystems Eng., 95(4), 473-481. https://doi.org/10.1016/j.biosystemseng.2006.08.004

[26] Stajnko, D., Berk, P., Lešnik, M., Jejčič, V., Lakota, M., Štrancar, A., Hočevar, M., \& Rakun, J. (2012). Programmable ultrasonic sensing system for targeted spraying in orchards. Sensors, 12, 15500-15519. https://doi.org/10.3390/s121115500

[27] Gamarra-Diezma, J. L., Miranda-Fuentes, A., Llorens, J. Cuenca, A., Gregorio, L., Blanco-Roldán., \& RodríguezLizana, A. (2015). Testing Accuracy of Long-Range Ultrasonic Sensors for Olive Tree Canopy Measurements. Sensors, 15, 2902-2919. https://doi.org/10.3390/s150202902

[28] Jurišić, M. \& Plaščak, I. (2009): Geoinformation Systems GIS in Agriculture and Environmental Protection. Osijek, Croatia: Agricultural faculty.

[29] Llorens, J., Gil, E., Llop, J., \& Escola, A. (2010). Variable rate dosing in precision viticulture: use of electronic devices to improve application efficiency. Crop Prot., 29, 239-248. https://doi.org/10.1016/j.cropro.2009.12.022

[30] Doruchowski, G., Swiechowski, W., Godyn, A., \& Holownicki, R. (2011). Automatically controlled sprayer to implement spray drift reducing application strategies in orchards. J. fruit Ornam. Plant Res., 19, 175-182. $\mathrm{http}: / /$ www.inhort.pl/files/journal pdf/journal 2011_1/full1 6\%202011_1_.pdf

[31] Chen, Y., Ozkan, H. E., Zhu, H., Derksen, R. C., \& Krause, C. R. (2013). Spray deposition inside tree canopies from a newly developed variable-rate air-assisted sprayer. Trans. ASABE, 56, 1263-1272. https://doi.org/10.13031/trans.56.9839

[32] Escola, A., Rosell-Polo, J. R., Planas, S., Gil, E., Pomar, J., Camp, F., Llorens, J., \& Solanelles, F. (2013). Variable rate sprayer. Part 1 orchard prototype: design; implementation and validation. Comput. Electron. Agric., 95, 122-135. https://doi.org/10.1016/j.compag.2013.02.004

[33] Sedlar, A. D., Bugarin, R. M., Nuyttens, D., Turan, J. J., \& Zoranovic, M. S. (2013). Quality and efficiency of apple orchard protection affected by sprayer type and application rate. Span. J. Agric. Res., 11, 935-944. https://doi.org/10.5424/sjar/2013114-3746

[34] Jeon, H. Y., Zhu, H., Derksen, R. C., Ozkan, H. E., Krause, C. R., \& Fox, R. D. (2011). Performance evaluation of a newly developed variable-rate sprayer for nursery liner applications. Trans. ASABE, 54(6), 1997-2007. https://doi.org/10.13031/2013.40648

[35] Banaj, Đ., Tadić, V., Banaj, Ž., \& Lukač, P. (2010). Improvement of pesticide application techniques, University textbook, Agricultural faculty in Osijek. https://hrcak.srce.hr/69551

[36] ISO TC 23/SC $06 \mathrm{~N}$ 22866:2005. Equipment for crop protection - Methods for the field measurement of spray drift. https://www.iso.org/standard/35161.html?browse=tc

\section{Contact information:}

Davor PETROVIĆ, MSc, professional associate

Faculty of Agrobiotechnical Sciences Osijek,

Vladimira Preloga 1, 31000 Osijek, Croatia

Tel: +385 31554848

E-mail: davor.petrovic@fazos.hr

Đuro BANAJ, PhD, Full Professor

Faculty of Agrobiotechnical Sciences Osijek

Vladimira Preloga 1, 31000 Osijek, Croatia

E-mail: djuro.banaj@fazos.hr

Anamarija BANAJ, MSc, Assistant

Faculty of Agrobiotechnical Sciences Osijek

Vladimira Preloga 1, 31000 Osijek, Croatia

E-mail: anamarija.banaj@fazos.hr

Željko BARAČ, MSc, Assistant

Faculty of Agrobiotechnical Sciences Osijek Vladimira Preloga 1, 31000 Osijek, Croatia

Email: zeljko.barac@fazos.hr

Ivan VIDAKOVIĆ, MSc, Assistant

Faculty of Agrobiotechnical Sciences Osijek Vladimira Preloga 1, 31000 Osijek, Croatia

E-mail: ivan.vidakovic@fazos.hr

Vjekoslav TADIĆ, PhD, Assistant Professor Correspoding author

Faculty of Agrobiotechnical Sciences Osiiek Vladimira Preloga 1, 31000 Osiiek, Croatia

E-mail: vjekoslav.tadic@fazos.hr 